\title{
Antiinflammatory effect of telmisartan on chronic obstructive pulmonary disease: 8-isoprostane concentration in exhaled breath condensate
}

\author{
Kronik obstruktif akciğer hastalı̆̆ında telmisartan'ın antiinflamatuar etkinliği: \\ Yoğunlaştırılmış soluk havasında 8-isoprostan konsantrasyonu
}

\author{
Abdülkadir Geylani Şahan, Abdülkerim Yılmaz, Türker Taşlıyurt*, Sibel Doruk, \\ Handan İnönü Köseoğlu, Hakan Şıvgın, Mustafa Sağcan \\ Department of Internal Medicine (A. G. Şahan, MD, Assoc. Prof. A. Yılmaz, MD, Assist. Prof. T. \\ Taşlıyurt, MD, H. Şıvgın, MD, M. Sağcan MD), Department of Pulmonary Diseases (Assist. Prof. \\ S. Doruk, MD, Assoc. Prof. H. İnönü Köseoğlu, MD), Gaziosmanpasa University School of \\ Medicine, TR-60100 Tokat
}

\begin{abstract}
Aim. Chronic obstructive pulmonary disease (COPD) is a chronic, progressive, inflammatory disease. Oxidative stress and airway inflammation are its main pathophysiologic components. In this study, our aim was to investigate the effect of an angiotensin receptor blocker (ARB) telmisartan which also exerts antiinflammatory effects on inflammation and oxidative stress in COPD. Method. The study group consisted of 50 stable COPD patients including 25 telmisartan users. Exhaled breath condensate (EBC) samples of the cases were collected using an EBC collecting device (Ecoscreen, Jaeger, Germany). EBC samples were analyzed and 8-isoprostane levels were measured using an enzyme immunoassay method (Cayman Chemical Co. Michigan, USA). Results. Any intergroup difference as for mean age, distribution of gender and smoking were not found. In telmisartan users, and nonusers mean 8-isoprostane levels were 33.98 and 35.91 $\mathrm{pg} / \mathrm{mL}$, respectively with a statistically significant intergroup difference $(\mathrm{p}<0.001)$ Conclusion. We think that ARBs decrease oxidative stress and inflammation, and thus exert favourable effects on the pathophysiology and progression of COPD.
\end{abstract}

Keywords: Chronic obstructive pulmonary disease, oxidative stress, 8-isoprostane, angiotensin receptor blocker, telmisartan

\section{Özet}

Amaç. Kronik obstrüktif akciğer hastalığı (KOAH) kronik, ilerleyici, inflamatuar bir hastalıktır. Oksidatif stres ve havayolu inflamasyonu hastalığın ana patofizyolojik etkenleridir. Bu çalıșmada bir anjiyotensin reseptör blokeri (ARB) olan telmisartan'ın KOAH'daki antiinflamatuar etkisini araştırmayı amaçladık. Yöntem. Çalışmaya 25'i telmisartan kullanan $50 \mathrm{KOAH}$ hastası alındı. Hastaların yoğunlaştırılmış soluk havası (EBC) örnekleri EBC toplama cihazı kullanılarak toplandı (Ecoscreen, Jaeger, Germany). EBC örnekleri analiz edildi ve enzim immunoassay metodu (Cayman Chemical Co. Michigan, USA) kullanılarak 8-izoprostan düzeyleri ölçüldü. Bulgular. Her iki grup arasında ortalama yaş, cinsiyet ve sigara kullanımı açısından fark yoktu. Telmisartan kullanan ve kullanmayan grupta 8-izoprostan düzeyleri sirasiyla 33,98 ve $35,91 \mathrm{pg} / \mathrm{mL}$ olarak ölçüldü, iki grup arasındaki fark istatistiksel olarak anlamlı bulundu ( $<<0,001)$. Sonuç. ARB'lerin oksidatif stres ve inflamasyonu azaltarak hastalığın patofizyolojisi ve ilerleyişine olumlu etkileri olabilir.

Anahtar sözcükler: Kronik obstrüktif akciğer hastalığı, oksidatif stres, 8-izoprostan, anjiyotensin reseptör blokeri, telmisartan 
Geliş tarihi/Received: April 02, 2013; Kabul tarihi/Accepted: June 04, 2014

\section{*Corresponding author:}

Dr. Türker Taşlıyurt, İç Hastalıkları Anabilim Dalı, Gaziosmanpaşa Üniversitesi Tıp Fakültesi, TR-60100 Tokat. E-mail: turtasliyurt@ hotmail.com

\section{Introduction}

Chronic obstructive pulmonary disease is characterized by chronic, progressive, partially reversible airflow limitation induced by an abnormal inflammatory pulmonary reaction caused by inhalation of noxious particles and gasses mainly cigarette smoke [1.].

COPD is a chronic inflammation consisting predominantly of neutrophils, and macrophages and, also interleukins, nitric oxide, and TNF- $\alpha$ play an effective role in its pathogenesis. Oxidative stress is another important factor in the pathogenesis of COPD, and oxidant-antioxidant balance is tipped in favour of oxidants [2, 3].

Among best biomarkers of oxidative stress, isoprostanes have a stable structure, and they are found in normal tissues, and body fluids [4]. 8-isoprostane is a F2 class isoprostane. It is synthetize from arachidonic acid through a nonenzymatic pathway secondary to oxidant agents. In healthy individuals the presence of 8 -isoprostane has been demonstrated in exhaled breath condensate (EBC) samples of healthy individuals which can be even detected within physiologic limits of oxidative stress [5, 6]. It has been encountered in higher levels in COPD patients, and in healthy smokers when compared with healthy nonsmokers [6]. It has been demonstrated that the level of 8-isoprostane in EBC was increased during exacerbations of COPD where severity of inflammation, and oxidative stress are aggravated relative to healthy individuals. In addition, decreased levels of 8-isoprostane have been demonstrated with medical therapy [7].

In renin-angiotensin system, angiotensinogen is converted to angiotensin -1 through the action of renin, and still, angiotensin-1 is transformed into angiotensin II in a process mediated by angiotensin converting enzyme (ACE) particularly found in the pulmonary circulation [8]. Since angiotensin-II induces oxidative stress and increased levels of inflammatory mediators acting on vascular system, angiotensin receptor blockers (ARBs) exert ameliorating effects on inflammation, and oxidative stress [9]. Many studies have demonstrated antiinflammatory effects of ARBs. In these studies also including telmisartan, favourable effects of ARBs have been displayed on diabetes mellitus and cardiovascular diseases which possess inflammatory properties [10-14]. ARBs are known to decrease inflammation, and oxidative stress which lead to complications in cardiovascular diseases, and diabetes mellitus [15].

Various studies have investigated levels of 8-isoprostane in COPD which is characterized by chronic inflammation, and oxidative stress involving airways $[5,16,17]$. Although many animal, and human studies have determined antiinflammatory effects of ARBs, limited number of studies have been encountered in the literature which investigated the effects of ARBs on inflammation in COPD. In this study, we aimed to investigate the effect of an ARB, ie. telmisartan on inflammation, and oxidative stress by analyzing EBC 8-isoprostane levels.

\section{Material and methods}

According to Global Initiative for Chronic Obstructive Lung Disease (GOLD) criteria [2] among patients diagnosed as Stage 2, and Stage 3 COPD, those in the steady state were evaluated. Twenty five patients who used telmisartan for at least one year were included in the study (Group I). Twenty five COPD patients who did not use any ARBs constituted the control group (Group II). Patients with active infection, uncontrolled diabetes mellitus, malignancy, asthma, allergic rhinitis, gastroesophageal reflux, users of 
nonsteroidal antiinflammatory drugs, and leukotriene receptor antagonists within previous one month were excluded from the study. The study protocol was approved by the Local Ethics Committee and informed consent was obtained from all participants.

Samples of EBC were collected using a condenser (EcoScreen, Jaeger, Würzburg, Germany). As defined by American Thoracic Society (ATS), and European Respiratory Society (ERS) guidelines the cases were asked to wear a noseclip, and breath for 15 minutes through a mouthpiece and a two way non-rebreathing valve which also served as a saliva trap at a normal frequency and tidal volume [18]. From each patient at least 1.5 $\mathrm{mL}$ samples of condensate were collected and stored immediately at $-80^{\circ} \mathrm{C}$.

EBC samples were kept at $4{ }^{\circ} \mathrm{C}$ for 24 hours for liquefication, and then brought under room temperature. The 8-isoprostane levels were measured in compliance with the directives set forth by the manufacturing firm (Cayman Chemical Co, USA) using an enzyme-linked immunoassay method (EIA).

\section{Statistical analysis}

Analysis were performed using commercial software IBM SPSS Statistics 15.00, SPSS inc., an IBM Co., Somers, NY), t-test and chi-square test were used for evaluating difference between the groups. A p value $<0.05$ was considered as significant.

\section{Results}

The mean age of the patients was $63.4 \pm 7.2$ years and $62.7 \pm 8.8$ years in group 1 and 2, respectively. In Group I, all patients were male, and Group II consisted of 23 (92\%) males and $2(8 \%)$ females. In both groups, 5 (20\%) patients were current smokers. A statistically significant intergroup difference was not found as for age, gender, and smoking status $(\mathrm{p}>0.05)$.

Mean 8-isoprostane levels in EBC, in groups I, and II were $33.95 \pm 37.00 \mathrm{pg} / \mathrm{mL}$, and $35.91 \pm 25.20 \mathrm{pg} / \mathrm{mL}$, respectively. 8-isoprostane levels were lower in telmisartan users relative to nonusers and the difference between the groups was statistically significant $(\mathrm{p}<0.001)$ (Table 1).

\section{Table 1. Main results of the study.}

\begin{tabular}{llll}
\hline & Group I (n: 25) & Group II (n: 25) & p \\
\hline Gender & & & *Non significant \\
\hline Male & 25 & 23 & \\
Female & - & 2 & $*$ Non significant \\
Mean age & $63.4 \pm 7.2$ & $62.7 \pm 8.8$ & $<0.001$ \\
Level of 8-isoprostane (pg/mL) & $33.95 \pm 37.00$ & $35.91 \pm 25.20$ & \\
\hline *p $>\mathbf{0 . 0 5}$ & & & \\
\hline
\end{tabular}

\section{Discussion}

In our study, as a biomarker of inflammation, the levels of 8-isoprostane were measured in samples of exhaled breath condensate obtained from COPD patients, and lower levels of 8-isoprostane were detected in telmisartan users relative to nonusers. Therefore our study determined antiinflammatory effects of ARBs in COPD.

Apart from primary antihypertensive indications of ARBs, especially their antiinflammatory effects have attracted attention of many investigators. In many human and animal studies, antiinflammatory effects of ARBs have been investigated. In studies performed with ARBs, investigators detected that candesartan, and telmisartan had decreased the formation of inflammatory mediators such as TNF- $\alpha$, interleukin $-1 \beta$, and interleukin -6 [12, 19]. Antiinflammatory effects of ARBs have been demonstrated in various clinical conditions as hypertension, radiation-related delayed inflammation, and inflammatory chronic hepatitis C [20-22]. In animal studies performed using ARBs, valsartan decreased inflammatory cell infiltration in bronchoalveolar lavage fluid in 
asthmatics, and losartan suppressed inflammatory processes in sepsis, and arthritis [2325]. Gemici et al. [26] detected antiinflammatory effects of candesartan in an animal model of ischemic reperfusion damage.

COPD is a disease characterized by chronic inflammation in airways, pulmonary parenchyma, and pulmonary vessels. Abundant evidence of both local and systemic inflammation have been found in patients with COPD. Various mediators such as leukotriene B4 and and TNF- $\alpha$ which induce destructive changes are released from activated inflammatory cells in COPD patients. In addition to inflammation, oxidative stress also plays an important role in the pathogenesis of COPD [2, 3, 27-29].

Despite several animal and human studies about anti inflammatory effects of ARBs, limited number of studies have investigated the effect of ARBs on inflammation and oxidative stress in COPD. In an emphysema model constructed by Raupach et al. [30] beneficial effects of irbesartan treatment on the severity of the disease, pulmonary biomechanics, and exercise capacity were reported.

Angiotensin II plays an important role in induction, and persistence of inflammation. As a result; inhibition of RAS might decrease the levels of systemic inflammatory biomarkers. Therefore, Mascitelli et al. [31] recommended use of ACE inhibitors or angiotensin II type I receptor blockers in many COPD patients, especially in those with pulmonary hypertension. In our study, lower levels of 8-isoprostane in EBC samples obtained from cases with COPD who were using telmisartan with the indication of hypertension when compared with nonusers tend to support recommendations of Mascitelli et al.

In a study performed by an ARB agent telmisartan, improvement in respiratory functions (FEV1 and PEF) and decrease in bronchial resistance, and arterial blood PCO2 levels were detected [32].

Some studies have investigated other effects of ARBs on different mechanisms involving in COPD apart from their antiinflammatory effects. Andreas et al. [33] evaluated impact of angiotensin II receptor blockers on activities of skeletal and respiratory muscles. In COPD, increased sympathetic, and RAS activities exert an unfavourable impact on skeletal muscles. Angiotensin II receptor blockers might effect skeletal, and respiratory muscles favourably. To recommend ARBs in COPD because of these beneficial effects requires conduction of further studies.

Our results suggest potential alleviating effects of ARBs on the inflammation of COPD. In COPD, inflammation preventing treatments have been used, however any treatment protocol which precludes disease progression is lacking. Especially in cases with COPD associated with comorbidities like hypertension, for the determination of contributory effects of adding inflammation suppressing, and oxidative stress decreasing agents such as ARBs to standard COPD therapies in deceleration of disease progression, large scale prospective clinical studies should be performed.

\section{References}

1. Rabe KF, Hurd S, Anzueto A, Barnes PJ, Buist SA, Calverley P. Global strategy for the diagnosis, management, and prevention of chronic obstructive pulmonary disease: GOLD executive summary. Am J Respir Crit Care Med 2007; 176: 532-55.

2. Global Initiative For Chronic Obstructive Lung Disease (GOLD) Updated 2008; 4: 24-30.

3. Owen CA. Proteinases and Oxidants as Targets in the treatment of Chronic Obstructive Pulmonary Disease. Proc Am Thorac Soc 2005; 2: 373-85.

4. Montuschi P. Exhaled breath condensate analysis in patients with COPD. Clin Chim Acta 2005; 356: 22-34. 
5. Carpenter CT, Price PV, Christman BW. Exhaled breath condensate isoprostanes are elevated in patients with acute lung injury or ARDS. Chest 1998; 114: 1653-9.

6. Montuschi P, Collins JV, Ciabattoni G, Lazzeri N, Corradi M, Kharitonov SA. Exhaled 8-isoprostane as an in vivo biomarker of lung oxidative stress in patients with COPD and healthy smokers. Am J Respir Crit Care Med 2000; 162: 1175-7.

7. Biernacki WA, Kharitonov SA, Barnes PJ. Increased leukotriene B4 and 8 -isoprostane inexhaled breath condensate of patients with exacerbations of COPD. Thorax 2003; 58: 294-8.

8. Inagami T, Senbonmatsu T. Dual effects of angiotensin II type 2 receptor on cardiovascular hypertrophy. Trends Cardiovasc Med 2001; 11: 324-8.

9. Savoia C, Schiffrin EL. Reduction of C-reactive protein and the use of anti-hypertensives. Vasc Health Risk Manag 2007; 3: 975-83.

10. Cianchetti S, Del Fiorentino A, Colognato R, Di Stefano R, Franzoni F, Pedrinelli R. Anti-inflammatory and anti-oxidant properties of telmisartan in cultured human umbilical vein endothelial cells. Atherosclerosis 2008; 198: 22-8.

11. Kyvelou SM, Vyssoulis GP, Karpanou EA, Adamopoulos DN, Gialernios TP. Beneficial effects of angiotensin II type 1 receptor blocker antihypertensive treatment on inflammation indices: The effect of smoking. J Clin Hypertens (Greenwich) 2007; 9: 21-7.

12. Larrayoz IM, Pang T, Benicky J, Pavel J, Sánchez-Lemus E, Saavedra JM. Candesartan reduces the innate immune response to lipopolysaccharide in human monocytes. J Hypertens 2009; 27: 2365-76.

13. Touyz RM, Savoia C, He Y, Endemann D, Pu Q, Ko EA. Increased inflammatory biomarkers in hypertensive type 2 diabetic patients: Improvement after angiotensin II type 1 receptor blockade. J Am Soc Hypertens 2007; 1: 189-99.

14. Sakuta T, Morita Y, Satoh M, Fox DA, Kashihara N. Involvement of the renin-angiotensin system in the development of vascular damage in a rat model of arthritis: Effect of angiotensin receptor blockers. Arthritis Rheum 2010; 62: 1319-28.

15. Dandona P, Dhindsa S, Ghanim H Chaudhuri A. Angiotensin II and inflammation: The effect of angiotensin-converting enzyme inhibition and angiotensin II receptor blockade. J Hum Hypertens 2007; 21: 20-7.

16. Anthonisen NR, Manfreda J, Warren CP, Hershfield ES, Harding GK, Nelson NA. Antibiotic therapy in exacerbations of chronic obstructive pulmonary disease. Ann Intern Med 1987; 106: 196-204.

17. Carpagnano GE, Kharitonov SA, Foschino-Barbaro MP, Resta O, Gramiccioni E, Barnes PJ. Increased inflammatory markers in the exhaled breath condensate of cigarette smokers. Eur Respir J 2003; 21: 589-93.

18. ATS/ERS recommendations for standardized procedures for the online and offline measurement of exhaled lower respiratory nitric oxide and nasal nitric oxide, 2005. American Thoracic Society; European Respiratory Society Am J Respir Crit Care Med 2005; 171: 912-30.

19. Tian Q, Miyazaki R, Ichiki T, Imayama I, Inanaga K, Ohtsubo H. Inhibition of tumor necrosis factor-alpha-induced interleukin- 6 expression by telmisartan through cross-talk of peroxisome proliferator activated 
receptor-gamma with nuclear factor kappaB and CCAAT/enhancerbindingprotein beta. Hypertension 2009; 53: 798-804.

20. Benicky J, Sánchez-Lemus E, Pavel J, Saavedra JM. Anti-inflammatory effects of angiotensin receptor blockers in the brain and the periphery. Cell Mol Neurobiol 2009; 29: 781-92.

21. Zhao W, Robbins ME. Inflammation and chronic oxidative stress in radiation-inducedlate normal tissue injury: Therapeutic implications. Curr Med Chem 2009; 16: 130-43.

22. Colmenero J, Bataller R, Sancho-Bru P, Domínguez M, Moreno M, Forns $\mathrm{X}$. Effects of losartan on hepatic expression of nonphagocytic NADPH oxidase and fibrogenic genes in patients with chronic hepatitis C. Am J Physiol Gastrointest Liver Physiol 2009; 297: 726-34.

23. Wang T, Yin KS, Liu KY, Lu GJ, Li YH, Chen JD. Effect of valsartan on the expression of angiotensin II receptors in the lung of chronic antigen exposure rats. Chin Med J (Engl) 2008;121: 2312-9.

24. Hagiwara S, Iwasaka H, Hidaka S, Hasegawa A, Koga H, Noguchi T. Antagonist of the type-1 ANG II receptor prevents against LPS-induced septic shock in rats. Intensive Care Med 2009; 35: 1471-8.

25. Sakuta T. Involvement of the renin-angiotensin system in the development of vascular damage in a rat model of arthritis. American College of Rheumatology 2010; 62: 1319-28.

26. Gemici B, Tan R, Ongüt G, Izgüt-Uysal VN. Expressions of inducible nitric oxide synthase and cyclooxygenase-2 in gastric ischemiareperfusion: Role of angiotensin II. J Surg Res 2010; 161: 126-33.

27. Gan WQ, Man SF, Senthilselvan A, Sin DD. Association between chronic obstructive pulmonary disease and systemic inflammation: A systematic review and a metaanalysis. Thorax 2004; 59: 574-80.

28. Pinto-Plata VM, Müllerova H, Toso JF, Feudjo-Tepie M, Soriano JB, Vessey RS. C-reactive protein in patients with COPD, control smokers, and nonsmokers. Thorax 2006; 61: 1-3.

29. Eid AA, Ionescu AA, Nixon LS, Lewis-Jenkins V, Matthews SB, Griffiths TL. Inflammatory response and body composition in chronic obstructive pulmonary disease. Am J Respir Crit Care Med 2001; 164: 1414-8.

30. Raupach T, Lüthje L, Kögler H, Duve C, Schweda F, Hasenfuss G. Local and systemic effects of angiotensin receptor blockade in an emphysema mouse model. Pulm Pharmacol Ther 2011; 24: 215-20.

31. Mascitelli L, Pezzetta F. Renin-angiotensin system blockade and COPD. Chest 2006; 129: 1734-35.

32. Pavlishchuk SA, Bolotova EV, Porkhanov VA. Efficacy of telmisartan in chronic obstructive lung disease wtih arterial hypertension. Klin Med (Mosk) 2005; 83: 63-5.

33. Andreas S, Herrmann-Lingen C, Raupach T, Lüthje L, Fabricius JA, Hruska N. Angiotensin II blockers in obstructive pulmonary disease: A randomised controlled trial. Eur Respir J 2006; 27: 972-9. 